\title{
Public Service Performance of Civil Servants (PNS) at South Tondano District Office in Minahasa Regency
}

\author{
Natasha Katie Giroth, Marthinus Mandagi, Wilson Bogar \\ Manado State University, Minahasa, North Sulawesi, Indonesia \\ Email: natashagiroth@yahoo.com, marthinusmandagi@unima.ac.id, wilsonbogar@unima.ac.id
}

\begin{tabular}{|c|c|}
\hline ARTICLE INFO & 3STRACT \\
\hline $\begin{array}{l}\text { Received: 05-01-2022 } \\
\text { Revision: 13-01-2022 } \\
\text { Received : 18-01-2022 } \\
\text { Keywords: } \\
\text { Public services } \\
\text { performance; PNS (Civil } \\
\text { Servants); Government } \\
\text { workplace }\end{array}$ & $\begin{array}{l}\text { This study aims to analyze and explain the performance of civil } \\
\text { servants' public services at the Tondano Selatan District Office, } \\
\text { Minahasa Regency, based on indicators: (1) PNS professionalism in } \\
\text { providing services correctly and correctly, (2) awareness or desire } \\
\text { to help the community/customers and provide fast service, (3) } \\
\text { attitudes/behaviors and respect for consumers, (4) approaching } \\
\text { and trying to find out the wants and needs of consumers, (5) } \\
\text { availability and condition of office facilities and infrastructure at the } \\
\text { South Tondano District Office. This study used a qualitative } \\
\text { method. Data sources are determined by purposive and snowball } \\
\text { sampling, while data collection techniques include interviews, } \\
\text { observations, and documents. The results of study revealed the } \\
\text { service performance of civil servants at the South Tondano District } \\
\text { Office was based on indicators are 1) PNS professionalism in } \\
\text { providing services appropriately and correctly in terms of the } \\
\text { capabilities possessed by civil servants being able to provide the } \\
\text { best service, (2) Awareness or desire to help the } \\
\text { community/customers and provide fast service in this case civil } \\
\text { servants are demanded to have a high responsiveness to be able to } \\
\text { be responsive in providing services to the community by referring } \\
\text { to the SOP in the South Tondano District Office, (3) } \\
\text { Attitudes/behaviors, and respect for consumers in this case civil } \\
\text { servants in demand to uphold ethics and have a good personality } \\
\text { and also be able to communicate well in providing services (4) } \\
\text { Approach, and try to find out the wants and needs of consumers in } \\
\text { this case civil servants are expected to be able to fulfill the service } \\
\text { according to the wishes and needs of the community but still in } \\
\text { accordance by the rules doesn't happen. (5) The availability and } \\
\text { condition of office facilities and infrastructure in the South Tondano } \\
\text { District are expected to be improved and equipped to support } \\
\text { better services for public. }\end{array}$ \\
\hline
\end{tabular}

\section{Introduction}

The State Civil Apparatus (ASN) as a resource in organizations, such as the subdistrict office, is a fundamental asset and determines the success of an organization in achieving the vision, mission, and goals that have been set. No matter how sophisticated and complete other resources, such as equipment and finance, are available to an organization (sub-district office) without being supported by the capability and capacity of Human Resources (HR), namely qualified ASN, then these resources (equipment and finance) will not work and contribute optimally in achieving the success of the Giroth, N. K., Marthinus Mandagi, Wilson Bogar. (2022). Public Service Performance of Civil Servants (PNS) at South Tondano District Office in Minahasa Regency. Journal of Social Science, 3(1). https://doi.org/10.46799/jss.v3i1.286

E-Issn: 2721-5202

Published By: $\quad$ Ridwan Institut 
organization itself. The organization may experience difficulties and even failure in facing the challenges of increasingly fast and complex environmental changes. Ulrich (1998) says that the key to the success of a change is in human resources, namely as the initiator and agent of continuous change, forming processes and cultures that together increase the ability of organizational change. Research conducted by (Grant \& BadenFuller, 1995), (Azusa \& Hiroyuki, 2013) concluded that organizational resources could be a factor of excellence and improve organizational performance.

In public sector organizations, such as sub-district offices, ASN employees will be a factor or source of excellence in the organization if they make a real contribution or contribution to the organization (subdistrict office) carrying out its mission and objectives efficiently and effectively. The real contribution or contribution of ASN to the achievement of the organization's mission and goals will be seen, among others, in their performance in carrying out their respective duties and functions in providing services to the community. It is also emphasized in Law Number 5 of 2014, concerning State Civil Apparatus (ASN) article 3 that ASN as a profession is based on principles, including commitment, moral integrity, and responsibility for public services. Furthermore, Article 4 states that in carrying out this principle, ASN adheres to fundamental values, including being accountable for their actions and performance to the public; having the ability to implement government policies and programs; providing services to the public in an honest, responsive, fast, precise, accurate, efficient, effective and polite manner.

ASN consisting of Civil Servants (PNS) and Government Employees with Work Agreements (PPPK) as public servants must be able to place the positions as subjects and actors in service to the community, not the other way around as objects, namely asking to be served, as there are still many complained by various parties. ASN as a bureaucratic apparatus must simplify all matters in public services so that the bad image of the bureaucracy about public services is increasingly being improved and the level of public trust in the performance of the bureaucracy in which ASN is getting better. There are no more complaints and accusations from the public that public services carried out by bureaucratic apparatus or ASN are convoluted, not transparent, unfriendly, without certainty, and discriminatory, all of which are a manifestation of poor public service performance.

It should be acknowledged that efforts to improve the performance of public services for ASN as a bureaucratic apparatus have been and are even being actively implemented and have brought results to improving the performance of public services, but along with the rapid development of needs and demands of the public (community) for services itself, concerning the quality of public service performance that does not meet public expectations is also always complained of or voiced by the public.

Public services in the sub-district are comprehensive, which can be seen in The Mayor of region duties as the leader. This task is stipulated in Government Regulation Number 17 of 2018, especially in Article 10, which is described into nine matters relating to the task of managing, coordinating and the task of fostering and supervising, and carrying out other tasks following the provisions of the legislation and in Article 11 given the task of delegation about the authority of the regent/mayor, such as licensing and non-licensing services.

Concerning the duties of the subdistrict government, the Minahasa Regent has issued Minahasa Regent Regulation No. 48 of 2016 concerning the position, organizational structure, duties, and work procedures of the Sub-district and Sub-District, which in articles 13 to 17 explain the duties of the sections (5 sections), namely the government section, the public peace and order section, the 
community and village empowerment section, the social welfare section, and the public service section. In particular, this research is focused on the government section because services to the community are carried out directly by the government section, such as services for managing Land Deeds, Deeds of Sale and Purchase (AJB), BPTH, and Delegation of Problems.

Based on the pre-survey through observations and interviews with people who are currently being served and have finished being served, it turns out that complaints such as their expectations for the service performance of officers, in this case, ASN, especially civil servants, are still expressed by people who deal with or request services at the South Tondano District Office, Minahasa Regency. Therefore, the authors are interested in researching the Public Service Performance of Civil Servants at the South Tondano District Office, Minahasa Regency.

The focus of the problem is: Public Service Performance of Civil Servants at the South Tondano District Office, Minahasa Regency, under the tasks given and will be carried out by the sub-district, which has been legally stipulated in Government Regulation Number 17 of 2018, especially in Article 10 and Article 11. As stated in the section, the background of the problem is that the sub-district tasks will be carried out by the sub-district head and distributed to all of his apparatus (ASN) following their main tasks, so that this research only focuses on the tasks of the Government Section in
Regent Regulation No. 48 of 2016, because this section is more related to public services.

1. How is the professionalism of civil servants at the South Tondano Office in providing services?

2. How is the awareness/desire of employees in helping and providing services at the South Tondano District Office?

\section{Method}

This study uses a qualitative approach. Qualitative research is used to get an accurate overall picture of the research object (Arikunto, 2010). According to (Sugiyono, 2013), qualitative research seeks to describe and interpret what exists (it can be about existing conditions or relationships, growing opinions, ongoing processes, consequences or effects that occur or trends that are developing).

In this study, researchers want to describe, examine and analyze the performance of public services in South Tondnao District. From the professionalism of employees, awareness/desire of employees in helping and providing services, attitudes/behaviour and respect for consumers, suitability of consumer wants and needs, and existing infrastructure facilities at the South Tondino District Office. The implementation of descriptive research methods is not limited to collecting and compiling data but includes reviewing, analyzing and describing the data to achieve the research objectives.

Table 1

PNS Public Service Performance in South Tondano District

Variable
Prepare work programs and




\begin{tabular}{l} 
activities \\
\hline 3. Carry out coordination and \\
synchronization of planning with \\
regional apparatus and vertical \\
agencies in the field of \\
implementing government \\
activities
\end{tabular}

4. Carry out the guidance and supervision of the orderly administration of the village government

5. Carry out guidance, supervision, facilitation and consultation on the implementation of village administration

6. Carry out coaching and supervision of the old law and the village head

7. Carry out coaching and supervision of village officials, old laws and village heads

8. To evaluate the implementation of government activities in the sub-district area.

9. Carry out an evaluation of the administration of village government at the sub-district level.

10. Carry out other tasks assigned by the the head of village

11. Carry out the preparation and reporting of activities

In this study, the performance of PNS public services at the South Tondano District Office is focused on analyzing and explaining the performance of public services, which include indicators: (1) PNS professionalism in providing services, (2) Effectiveness and efficiency in providing services, (3) Responsiveness and responsiveness to consumers, (4) Conformity to consumer wants and needs. (5) Availability and condition of office facilities and infrastructure at the South Tondano District Office.

\section{Results And Discussion}

South Tondano District is one of the subdistricts in the capital area of the Minahasa Regency. It is a medium land area with an
Coordination and synchronization of planning with regional apparatus and vertical agencies

Guidance and supervision of the orderly administration of the village government

Guidance, supervision, facilitation and consultation on the implementation of village administration

Guidance and supervision of the village head

Guidance and supervision of village officials and village head

Carry out an evaluation of the implementation of government activities in the sub-district area.

Carry out an evaluation of the administration of village government at the sub-district level.

Public service activities, namely the processing of land documents (land certificates, sale and purchase certificates, BPHTB) and civil registration

- Written report

- Verbal report

average altitude of 700 meters above sea level, located at 2022' north latitude and 3048' south latitude, and 119022' and 124022 ' east longitude. The area of South Tondano is $61,841.29 \mathrm{~km}^{2}$.

Public Service Performance of Civil Servants at the South Tondano District Office.

As one element of ASN, PNS is a government apparatus or bureaucracy that carries out government, development, and social tasks under the duties and functions it carries out. In this context, civil servants are obliged to provide the best or quality service as a tangible form of the results or performance that is realized (performance). The level of performance of public services embodied by the service provider or service 
provider can be known from the response of the service recipient or the community, namely whether the service received is appropriate or even higher or greater, or on the contrary, lower or smaller than what he expected. Suppose the service received is appropriate or even higher or more significant than expected. In that case, this will be assessed or responded to with a satisfied or very satisfied attitude for the service received. On the other hand, if the service received is lower or smaller than what he expected, this will be assessed or responded to with an attitude of being dissatisfied or dissatisfied with the service he received. Satisfaction with public services in this way will be a measure of the performance of public services provided and carried out by each provider and public service provider. In other words, satisfaction (satisfied or dissatisfied) with services as a form of quality (quality or not/less quality) can also be a measure of performance (low to high) of public services provided and implemented.

Civil servants are public servants, and the sub-district office as providing institutions and public servants must be proactive and creative and innovative in responding to and utilizing technological developments as the demands or needs of today's society are very diverse, so that the considerations or decisions that are set and will be carried out on all provided and carried out by providers and public servants under the expected or quality service recipients as a form of performance shown or achieved.

\section{Discussion}

Public service performance as a result of work realized by public service institutions, e.g. the South Tondano sub-district office with all its components such as employees (PNS), is strived by the government to make the quality get higher provides continuous satisfaction to the community. The strategy taken by the government to implement it is through bureaucratic reform, including concerning bureaucratic reform that asks to be served into a serving bureaucracy.

According to (Thomas \& Grindle, 1994), the policy (policy) of public service reform must be directed at observing and fixing various past policy mistakes and current policies and existing institutional regulatory mechanisms. The reform of public services must involve fundamental changes in administrative work routines, bureaucratic culture, and work procedures of government agencies to enable the development of leadership with a populist character in the public bureaucracy.

By changing the bureaucracy's characteristics into a serving bureaucracy, it will have an impact on increasing public trust in the government. This is also emphasized by (Vigoda-Gadot \& Mizrahi, 2014) that bureaucratic reform as an effort to realize a clean, accountable, effective, efficient, and quality government also aims to build public trust in the government. On the other hand, public trust can also benefit governance, including reducing transaction costs in administering the government, increasing the legitimacy of policies taken by the government, and increasing social capital, especially in the relationship between government and society.

According to (Widjanarko, 2016) to encourage contextualization of bureaucratic reform, each agency needs to develop dynamic governance based on values and culture. The dynamic governance framework, which is based on the principles of anticipatory, reflective, and innovative thinking (think ahead, think again, think across), is one of the frameworks of thought and work that government agencies can use. Based on the contextualization of bureaucratic reform, the government is better prepared institutionally to solve the problems it is currently facing and has the right mental capital to face other challenges in the future.

Adiperdana and Ak (2017) stated that in creating a clean, competent, and serving bureaucracy, he must demand immediate and 
rapid improvements or changes, known as mental revolutions, regarding changes in the mindset of the apparatus, culture, and institutional structure. The research findings are discussed in succession in the following.

\section{Public service performance is based on indicators of PNS professionalism in providing services}

The findings of this study reveal that the performance of civil servants' public services at the South Tondano District Office in terms of indicators of professionalism in providing services correctly and correctly has shown the professionalism that is expected to produce appropriate and correct public service performance.

The results of this study are in line with Erlando (2012) research on the analysis of the effect of service excellence on customer satisfaction, revealing that one of the variables that influence excellent service is the ability variable, in this case, the professionalism of service providers. Likewise, the results of research Barata (2004) excellent service variables are ability, attitude, appearance, attention, action, and accountability. Then Swastika (2005), in research on excellent service, focuses on six variables that represent it, namely ability, attitude, appearance, attention, action and accountability.

The ability to serve officers/employees can be improved through the learning process or educational process, be it formal education, non-formal education, in the form of in-service training and/or other training, which aims to increase capability and capacity as a public servant. It could also be the ability (ability) through self-study (selftaught). Sedarmayanti and Rahadian (2018) argue that professionalism is a pillar that will place the bureaucracy as a practical machine for the government and as a parameter of the apparatus' skills in working well, efficiently and effectively.

The government has carried out various efforts to improve public services, but not many have given a positive assessment of the performance of public services. The provision of services that are considered less professional and officials who tend to show attitudes as rulers and do not show attitudes as services are one form of an accusation that is addressed to service providers. This accusation is certainly not without reason, and there are often service officers who quickly leave the service counter because they prefer to fulfil the boss's call, an unfriendly attitude because they feel needed, providing unclear information gives the impression that the service officer does not understand the products/services provided. As a result of this unclear information, service users often have to go back and forth to the service place because the requirements are considered incomplete. The assessment is still coupled with statements from users, the need to provide "tips" if you want to finish quickly (Damayanti, Subekti, \& Baridwan, 2015).

Furthermore, (Damayanti et al., 2015), in his article on Eliminating Priyayi's Image in Providing Services, admits that the achievements in public service management that some service units and several regions have achieved are proof that the government has been continuously improving public services for a long time. The government's attention in providing quality public services is certainly not in doubt, although so far it has not provided maximum results in the eyes of the user community. Of course, efforts to make these improvements must be continuously carried out.

Furthermore, in the context of increasing the capacity and professionalism of bureaucratic apparatus resources, a roadmap for the transformation of the bureaucracy and human resources of the apparatus has been formulated, wherein 2025 it is expected that human resources will become human capital to face dynamic or governance. governance) towards a clean, competent and serving bureaucracy.

According to (Thomas \& Grindle, 1994), the policy (policy) of public service 
reform must be directed at observing and correcting various policy mistakes in the past and current policies and existing institutional regulatory mechanisms. The reform of public services must involve fundamental changes in administrative work routines, bureaucratic culture, and work procedures of government agencies to enable the development of leadership with a populist character in the public bureaucracy.

The national bureaucratic reform strategy (Kemenristekdikti, 2016:2) is macro directed within the framework of organizing national regulations and establishing 9 (nine) programs to accelerate bureaucratic reform, namely (1) restructuring the government organizational structure, (2) structuring the number and distribution of civil servants, (3) developing an open selection and promotion system, (4) increasing the professionalism of civil servants, (5) developing an integrated electronic government system, (6) improving public services, (7) increasing the integrity and accountability of the performance of the apparatus, (8) improving the welfare of civil servants. (9) increased efficiency of personnel spending. Meanwhile, the national bureaucratic reform strategy is micro directed at 8 (eight) areas of change, namely (1) Organization, which is an organization with the proper function and the right size; (2) Management, namely systems, processes and work procedures that are clear, effective, efficient, measurable and in accordance with the principles of good governance; (3) laws and regulations, namely regulations that are more orderly, non-overlapping and conducive; (4) human resources, namely human resources of the apparatus with integrity, neutral, competent, capable, professional, high-performing and prosperous; (5) supervision, namely increasing the administration of government that is free of KKN; (6) accountability, increased capacity and accountability of bureaucratic performance; (7) public services, namely excellent service according to the needs of the community; (8) mental apparatus, namely the creation of a positive work culture for the bureaucracy that serves, is clean and accountable.

Concerning the arrangement of national regulations regarding the management of human resources for the apparatus, Law Number 5 of 2014 concerning the State Civil Apparatus has been stipulated and issued, which is one of its considerations stated that in order to realize the State civil apparatus as part of bureaucratic reform, it is necessary to stipulate the state civil apparatus as a profession that has an obligation to manage and develop itself and is obliged to account for its performance and apply the principle of merit in the implementation of the management of the state civil apparatus;

Functions, duties and roles of ASN Employees (UU 5/2014), namely ASN employees function as (1) implementers of public policies; (1) public service; and (3) glue and unify the nation (article 10), and has the task of (1) implementing public policies made by the Civil Service Supervisory Officer under the provisions of the legislation; (2) provide professional, and quality public services; and (3) strengthen the unity and integrity of the Unitary State of the Republic of Indonesia (article 11) and play a role as a planner, implementer, and supervisor of the implementation of general government tasks and national development through the implementation of policies and public services that are professional, free from political intervention, and free from practices of corruption, collusion, and nepotism.

Based on the consideration of Law Number $5 / 2014$, that the implementation of the management of the State Civil Apparatus applies the principle of a merit system. Merit System is a policy and ASN Management based on qualifications, competence, and performance fairly and reasonably without distinction of political background, race, colour, religion, origin, gender, marital status, age, or disability condition. This system is implemented to ensure the management of 
apparatus resources (ASN) starting from recruitment based on the common principles of transparency, accountability and equality, so that qualified, competent, integrity and non-discriminatory employees are obtained, which ultimately improves the quality of public service performance.

\section{Public service performance is based on indicators of Awareness or desire in helping the community/customers and providing services.}

This study found that the performance of PNS services at the South Tondano District Office seen from the indicators of Awareness or desire in helping the community/customers and providing fast service had not been implemented as stipulated.

The results of this study support the results of research from (Hamka, 2019) on the quality of public services: Implications of Institutional Reorganization of Regency/City Governments which found, among other things, that on indicators of efficiency in public services, responses tend to give negative assessments of the government in public services. This shows that the local government has not been able to provide reliable services according to the community's expectations. This shows that the level of speed of local governments in providing services is still low.

(Purwanto, Pramusinto, \& Indiahono, 2018) confirmed that good ASN actions and behaviour would significantly affect efforts to improve the quality of public services. The awareness of all ASN members to contribute to efforts to improve the quality of public services in Indonesia will have significant long-term strategic implications for efforts to change the performance of the bureaucracy in providing public services. Why is that? if all ASN members have the same intention, then the aggregate of those individuals will be very powerful

For this reason, it is necessary to change the mindset (mindset) of the bureaucratic apparatus as a public servant. (Adiperdana \& Ak, 2017) explained that in creating a clean, competent, and serving bureaucracy, it must demand immediate and rapid improvements or changes or known as mental revolutions, regarding changes in the mindset of the apparatus, culture and institutional structure.

Concerning the mental revolution movement as a form of mindset change effort (mindset). (Adiperdana \& Ak, 2017) emphasized that this must be focused on the core mentality values, which are the essence of the Pancasila values, namely independence, cooperation, and the spirit of service to the community. Public. The value of independence is intended so that the Indonesian people are not trapped in an attitude of not being independent, depending on other nations, like to imitate, etc. The whole mental block that is not independent makes the Indonesian people less confident in their abilities. The value of cooperation is intended so that the value of mutual assistance in a positive frame to build the nation is consistently grown and practised or realized in the nation's life. In the context of implementation in the bureaucratic environment, the value of gotong royong (cooperation) can be carried out through harmonious coordination between agencies and eliminating sectoral egos. The government bureaucratic apparatus must change the mindset too, "Together everything can be achieved for the glory of the nation. The value of the spirit of service to the community is intended so that physical or non-physical symbols, self-perceptions, attitudes and behaviour as bureaucrats as rulers must be changed into public servant figures.

According to (Purwanto et al., 2018), the operationalization of a bureaucratic culture that serves the community can be done by: having a code of ethics to regulate what things are ethically allowed and not to be done, making the principle of serving as a pride, having a code of conduct or Clear SOPs 
in providing services, having professional ethics as a bureaucrat.

\section{Public service performance based on indicators of attitude/behavior and respect for consumers}

The findings of this study reveal that the performance of civil servants' public services at the South Tondano District Office based on indicators of attitude/behaviour and respect for consumers is perceived as not being realized or appropriately implemented.

Usman (2011) in his research on Professional Bureaucratic Management in Improving Public Services concluded that to overcome the problem of bureaucratic setbacks in terms of public services as a "solution" the strategies include: (1) changing the perception and paradigm of the bureaucracy regarding the concept of service; (2) the existence of a public policy that prioritizes the public interest and public services compared to the interests of certain rulers or elites; (3) elements of government, private sector and society must be all together in synergy; (4) the existence of regional regulations that are able to explain the minimum standards of public services and the sanctions that will be given; (5) the existence of a precise social supervision mechanism regarding public services between bureaucrats and the people served; (6) the existence of strong leadership in implementing public service commitments; (7) the existence of reforms in the field of public administration system; and (8) the existence of efforts to empower the community (empowerment) continuously and democratically.

In the reciprocal relationship between the government as a service provider and the public as a user, there are several things that service providers must pay attention to. According to Nisjar (Sedarmayanti, 2009), service providers must pay attention, namely (1) service procedures must be easy to understand and easy to implement, to avoid time-consuming practices; (2) services are provided clearly and definitely so that there is clarity for users; (3) effective and efficient service delivery; (4) fast and timely service, and (5) in various service activities, both technical and administrative, users are always treated with the motto customer is king and always right.

In the context of ASN as a service provider, the process of changing ASN behaviour as a manifestation of the implementation of a mental revolution needs to be accompanied by changes in the service management system that are closer to services that favour the needs of the community. Information Technology-based service management is currently more suitable for developing quality services, especially with Indonesia's geographical conditions. The online system is proven to eradicate KKN practices, providing faster services, both in terms of completion and service opening hours. An example of success in online services is the service change implemented in Fiduciary Services. Previously, it took three months to complete the service process, and now it can be completed in seven minutes.

Some of the prime service behaviours that need to be cultivated in organizations, according to (Purwanto et al., 2018), include (1). Greet and greet, (2). Friendly, (3). Fast and on time, (4). Listen patiently and actively, (5). Neat appearance, (6). Do not forget to say thank you, (7). Remembering the customer's name, and (8). Treat customers well. In addition to these eight behaviours, what can be used as a reference in providing services is the principle of tender loving care (treating other people/customers as they want to be treated).

The performance of public services based on conformity/wants and needs expected by consumers

The findings of this study reveal that the performance of civil servants' public services at the South Tondano District Office based on indicators of conformity/wants and 
consumer needs has not been appropriately implemented.

Public services aim to meet the needs of service recipients (community/consumers) or provide satisfaction to them. For this reason, it is necessary first to know the needs needed by the community/consumers before providers and service providers carry out public services. (Adiperdana \& Ak, 2017) reveals that a good understanding of public needs and preferences enables the government to optimize the services. Understanding the level of public assessment of the speed and cost of different service times allows the government to redesign services to increase user satisfaction within the available budget.

When providing public services, understanding the needs of service recipients will produce an excellent response to the quality or performance of the service received with a sense of satisfaction. The quality of public services is a measure of the performance of public services to realize services that provide satisfaction to the community as a form of excellent service (excellent services). According to Tumilantouw, Mandagi, and Bogar (2020) excellent service is not just providing a service; it requires a little extra service and is by the expectations of customers who expect the best service. This makes employees who work in agencies make the right choices, steps, attitudes in dealing with customers. Furthermore, excellent service was developed based on the $3 \mathrm{~A}$ principles. First, we must present the right attitude, second, we must give undivided attention, third, above all, customers are looking for action. Excellent service based on the Attitude concept includes three principles, namely (1) serving customers based on a polite and harmonious appearance, (2) serving customers with positive, healthy and logical thinking, (3) serving customers with respect. Excellent service based on Attention includes three principles, namely (1) listening and truly understanding the needs of customers, (2) observing and appreciating customer behaviour, (3) devoting full attention to customers. Excellent service based on Action includes five principles, namely (1) recording every order/business/customer's needs, (2) recording customer needs, (3) reaffirming customer needs, (4) realizing customer needs, (5) expressing gratitude in the hope that the customer will return (Bogar, 2020; Mandagi \& Mantiri, 2020).

Based on the views expressed by the experts, it can be seen that the performance of public services, which is known through the quality of public services (excellent service) that provides customer satisfaction, could be achieved if the service provider involves the service recipient (community/customer), to find out the (society/customers) needs and wants (expectations). This means that it takes the participation of the service recipients so that the quality of services or public services provided and provided is responded positively or well by service recipients with satisfied or very satisfactory quality as excellent services (excellent services). For this reason, the creativity and innovation of service officers are needed to understand the needs of the communities it serves.

A good understanding of public needs and preferences enables the government to optimize the services. Understanding the level of public assessment of the speed and cost of different service times allows the government to redesign services to increase user satisfaction within the available budget (Adiperdana \& Ak, 2017).

This statement emphasizes that efforts to understand or know the needs and desires of the community as service recipients are a factor that significantly determines the success of public services. Means public services provide quality public service performance or provide excellent satisfaction.
Public service performance based on indicators of availability of office facilities and infrastructure


The findings of this study reveal the performance of civil servants' public services at the South Tondano District Office in terms of tangible indicators, such as the availability of office facilities and infrastructure, is not adequate following the expected needs.

The results of this study are in line with the results of Zainudin's research which found that limited facilities and physical infrastructure such as office buildings, meeting rooms and/or multi-purpose rooms, other facilities such as office equipment including computer equipment, mobility facilities, frequent power outages caused service performance to be less effective.

Likewise, the results of Erlando (2012) research on the analysis of the influence of service excellence on customer satisfaction revealed a significant joint influence on excellent service, namely the variables of ability, appearance, action, responsibility, accuracy, attitude, attention and comfort on customer satisfaction.

It is said that the results of this study state that the quality of public services for civil servants at the South Tondano District Office based on these indicators has not been as expected because it is under the Decree of the Minister of State Apparatus Empowerment No. 63/KEP/M.PAN/7/2003, wherein this policy has 15 indicators been formulated and identified as a measure to assess the quality of public services; the indicators are (1) Security, which means the process and public service products provide a sense of security and legal certainty, (2) Completeness of facilities and infrastructure, means the availability of adequate work facilities and infrastructure and other supports including the provision of telecommunications and information technology facilities. Provision of adequate service facilities and infrastructure by public service providers, (3) Ease of access, namely places, locations and service facilities that are adequate, easily accessible by the public, and can utilize telecommunications and information technology, (4). Convenience, namely the service environment, must be orderly, provided a comfortable, clean, tidy waiting room, a beautiful and healthy environment, and equipped with service support facilities such as parking, toilets, places of worship, and others.

Likewise, Maddy (2009) suggests that service quality includes the following indicators: a. Timeliness of service related to waiting time and process $b$. Service quality is related to the accuracy or accuracy of service c. Service quality is related to the courtesy and friendliness of business peopled. Service quality is related to responsibility in handling customer complaints, e. Service quality is related to the number of officers serving and other supporting facilities $f$. The quality of service is related to the location, the room where the service is, the parking lot, the availability of information, and other instructions/guidelines. g. Service quality relates to environmental conditions, cleanliness, waiting rooms, air conditioning, communication tools, etc.

\section{Conclusion}

It can be concluded that the performance of civil servants' public services at the South Tondano District Office is still not as expected or still perceived as unsatisfactory. It is hoped that it can be improved to achieve better services in the future. This can be known through the assessments and views given by research informants regarding several indicators of public service performance at the South Tondano District Office, such as:

The performance of civil servants' public services at the South Tondano District Office is seen based on indicators of PNS professionalism in providing services that the employees are sufficiently capable and responsible in providing services, expected to continue or update their abilities to adapt to consumer needs development and regulatory consequences of existing policies.

The performance of civil servants' public services at the South Tondano District 
Office based on indicators of employee awareness/desire in helping and providing services, it was revealed that the employees did not fully have the awareness to help the community in providing services, judging from the service procedure it had not been carried out properly. Thus, it is highly expected that employees can improve work ethic and use existing guidelines to achieve fast and appropriate service rightfully.

The performance of civil servants' public services at the South Tondano District Office based on indicators of attitude/behaviour and respect for consumers is revealed, or it is perceived that it has not been realized or appropriately implemented because there are still consumer complaints stating that the employees are not fully disciplined, some are still being indifferent and respect for consumers is still lacking, it is highly expected that the existing apparatus/employees can improve attitudes/behaviours to make consumers feel valued and happy in getting service.

The performance of civil servants' public services at the South Tondano District Office based on indicators of the suitability of consumer wants and needs, it was revealed that it had not been appropriately implemented since communication between the community and the apparatus had not fully understood each other, and services were expected to meet the needs of the community but should guided by the existing rules.

The performance of civil servants' public services at the South Tondano District Office based on indicators of the availability of office facilities and infrastructure, it turns out that it is not adequate under the expected needs, the lack of facilities certainly affects the service, for that it is hoped that the government in the South Tondano District Office must complete the facilities which are still lacking and could improve existing facilities.

\section{Suggestions}

The professionalism of civil servants needs and must constantly be developed due to the increasing demands of consumer needs to provide excellent and good quality service.

The work motivation of civil servants in South Tondano District needs to be increased to make awareness of providing excellent service to consumers is getting better, faster and more precisely based on the standards.

The character of civil servants is expected to be well-formed to obtain reliable human resources since to achieve excellent service it is not only assessed from the speed and accuracy of administration but also supported by human resources as a wheel in running the organization, in this case, human resources as public servants.

Communication needs to be built between civil servants as service providers and the community as service recipient consumers to create understanding of each other about what consumers want and need in getting services but must be guided by the applicable rules. As a results, the services are received according to the wishes and needs of consumers but also not breaking the rules.

The existing facilities and infrastructure at the South Tondano District Office need to be maintenanced. Furthermore, the facilities need to be improved since this is supported component in providing services that make both employees and customers comfort.

\section{References}

Adiperdana, A., \& Ak, M. B. A. (2017). Implementasi Reformasi Birokrasi Melalui Revolusi Mental Birokrasi Sebagai Upaya Membentuk Pemerintahan Berkelas Dunia. Pendayagunaan Aparatur Negara, 18. Google Scholar

Arikunto, S. (2010). Metode peneltian. Jakarta: Rineka Cipta. Google Scholar

Azusa, K., \& Hiroyuki, Y. (2013). Organizational resilience: an investigation of key factors that promote the rapid recovery of organizations. 
Academic Journal of Interdisciplinary Studies, 2(9), 188. Google Scholar

Barata, A. A. (2004). Dasar-Dasar Pelayanan Prima Jakarta: PT. Elex Media Komputindo. Google Scholar

Bogar, W. (2020). Pengaruh Lingkungan Kerja dan Karakteristik Pekerjaan terhadap Burnout, Kepuasan Kerja, Komitmen Organisasi dan Intention to Leave (Studi pada Pegawai Perum Pegadaian di Sulawesi Utara). Jurnal Aplikasi Manajemen, 9(4), 1465-1475. Google Scholar

Damayanti, T. W., Subekti, I., \& Baridwan, Z. (2015). Trust and uncertainty orientation: An efforts to create tax compliance in social psychology framework. Procedia-Social and Behavioral Sciences, 211, 938-944. Google Scholar

Erlando, E. (2012). Analisis Pengaruh Pelayanan Prima (Service Excellence) Terhadap Kepuasan Pelanggan (Studi Pada Spbu Pertamina 34-12708).

Grant, R. M., \& Baden-Fuller, C. (1995). A knowledge-based theory of inter-firm collaboration. In Academy of management proceedings (Vol. 1995, pp. 17-21). Academy of Management Briarcliff Manor, NY 10510. Google Scholar

Hamka, B. (2019). Peran Budaya Organisasi Dalam Motivasi Kerja Pegawai Negeri Sipil (PNS) Di Kantor Kementerian Agama Kabupaten Mamasa. Jurnal Administrasi Publik Dan Politik, 4(2), 123-130. Google Scholar

Mandagi, M. M., \& Mantiri, J. (2020). Administration of Land Register in South Minahasa Regency. In 3rd International Conference on Social Sciences (ICSS 2020) (pp. 117-120). Atlantis Press. Google Scholar

Purwanto, E. A., Pramusinto, A., \& Indiahono, D. (2018). Politics-Administration on the Dynamic Relations of Elected Officials and Bureaucracy in the Recruitment of
Local Career Officials. Advances in Social Science, Education and Humanities Research, 191, 437-451. Google Scholar

Sedarmayanti, S., \& Rahadian, N. (2018). Hubungan Budaya Kerja dan Lingkungan Kerja Terhadap Peningkatan Kinerja Pegawai Pada Lembaga Pendidikan Tinggi. Jurnal IImu Administrasi: Media Pengembangan IImu Dan Praktek Administrasi, 15(1), 63-77. Google Scholar

Sugiyono, D. (2013). Metode penelitian pendidikan pendekatan kuantitatif, kualitatif dan R\&D. Google Scholar

Thomas, J. W., \& Grindle, M. S. (1994). Political leadership and policy characteristics in population policy reform. Population and Development Review, 20, 51-70. Google Scholar

Tumilantouw, N., Mandagi, M., \& Bogar, W. (2020). Optimalisasi Pelayanan Publik di Kantor Kecamatan Suluun Tareran Kabupaten Minahasa Selatan. Jurnal Mirai Management, 5(1), 76-95. Google Scholar

Ulrich, D. (1998). A new mandate for human resources. Harvard Business Review, 76, 124-135. Google Scholar

Usman, J. (2011). Manajemen Birokrasi Profesional dalam Meningkatkan Pelayanan Publik. Otoritas: Jurnal IImu Pemerintahan, 1(2). Google Scholar

Vigoda-Gadot, E., \& Mizrahi, S. (2014). The Bureaucracy-Democracy Paradox Revisited: A Challenge to Democracy in Turbulent Times. Managing Democracies in Turbulent Times, 83-120. Google Scholar

Widjanarko, E. (2016). Analisa Dampak Penerapan Kebijakan Peraturan Pemerintah No. 69 Tahun 2015 Terhadap Industri Perkapalan Indonesia. Institut Teknologi Sepuluh Nopember. Google Scholar 
Public Service Performance of Civil Servants (PNS) at South Tondano District Office in Minahasa Regency

\section{Copyright holder :}

Natasha Katie Giroth, Marthinus Mandagi, Wilson Bogar (2022)

First publication right :

Journal of Social Science

\section{This article is licensed under:}

(c) (i) (2) 